\title{
Physicochemical and sensory properties of corn starch custard soured with tamarind, soursop and lime
}

\author{
Khadijat O. Salami ${ }^{1}$, Azeezat A. Olorunlambe ${ }^{1}$, Boluwatife O. Adesina ${ }^{2}$, Femi F. Akinwande ${ }^{3}$, Amina M. Ahmed El- \\ Imam $^{4}$, Samson A. Oyeyinka ${ }^{1,5 *}$ \\ ${ }^{I}$ Department of Home Economics and Food Science, University of Ilorin, Faculty of Agriculture, Ilorin, Nigeria \\ ${ }^{2}$ Department of Food Science and Technology, Federal University of Agriculture, Faculty of Agriculture, Abeokuta, \\ Nigeria \\ ${ }^{3}$ Department of Food Technology, Yaba College of Technology, Lagos, Nigeria \\ ${ }^{4}$ Department of Microbiology, Faculty of Life Sciences, University of Ilorin, Nigeria \\ ${ }^{5}$ School of Agriculture and Food Technology, Alafua campus, University of South Pacific, Fiji
}

*Corresponding author: sartf2001@yahoo.com

\begin{abstract}
Custard is a convenient food product, similar to ogi in appearance and viscosity, but lacks the sour taste typical of ogi. In this study, extracts (10\% $w / w)$ from tamarind, soursop and lime was added to custard samples and the physicochemical and sensory properties of the mixture was analysed. Corn gruel was included as the reference sample. Carbohydrate was the major component of the corn gruel (61.72\%) and custard samples (66.27-74.42\%). Corn gruel had substantially higher protein content (18.03\%) than custard samples (8.03-8.62\%). Custard samples were more dispersible in water, showed higher swelling power and significantly higher peak and final viscosities than the corn flour sample. However, the addition of souring agent did not significantly alter the cooking time and pasting temperature of custard. Custard may be soured with lime, tamarind and soursop to improve dispersibility, consistency, appearance, viscosity and sourness without significant changes in the overall acceptability of the product.
\end{abstract}

Keywords: custard; physiochemical properties; tamarind; soursop; lime

\section{Introduction}

Custard powder is a fine textured dry food product made from corn starch (Okoye et al., 2008), commonly used as a breakfast cereals or used as weaning food in most developing nations of the world including the tropics (Tárrega and Costell, 2006). Custard paste or gruel is made by dissolving custard starch in water, followed by the addition of calculated amount of boiling water (Alimi et al., 2017a; Alimi et al., 2017b). Custard emerged as a convenient food product to mimic the traditional fermented cereal gruel called ogi (Salami et al., 2018). Ogi is widely consumed in many parts of Africa including Nigeria. The production process takes about 3 to 5 days depending on the level of sourness. According to Salami et al. (2018), the time required to ferment, mill and prepare ogi prompted the development of products such as custard. However, the sour taste, typical of the fermented gruel is lacking in custard (Salami et al., 2018). Thus, the addition of souring agents such as tamarind (Tamarindicus indica), lime (Citrus aurantifolia) and soursop (Annona muricata) may be required to impact the desired sourness in custard powder. Extracts from these fruits are known for their tart and tangy flavor due to the presence of tartaric acid (Akubor and Egbekun, 2007). These fruits are generally rich in organic acid which contributes to their acidity and sourness. The sourness of lime has been associated with the presence of high amounts of citric acid, while the presence of malic and tartaric acid confers sourness to soursop (Shankaracharya, 1998) and tamarind respectively (Obulesu and Bhattacharya, 2011).

Previous studies on custard focused on enriching the powder with protein sources such as soybean (Alake et al., 2016; Okoye et al., 2008) or the use of other starch sources such as cassava for the preparation of custard (Alake et al., 2016; Awoyale et al., 2016). Addition of defatted soybean flour up to 10 or $20 \%$ levels to cassava starch custard was reported to be acceptable by taste panel members (Alake et al., 2016). Furthermore, the addition of defatted soybean flour resulted in high water binding capacity which was associated with increase in protein content (Alake et al., 2016). Other studies on custard paste reported the use of composite starch from corn and banana starches for improved functionality and reduced digestibility (Alimi et al., 2017b).

Recently, some authors reported the use of fruit extract to enhance the sourness of flour from germinated cereal grains (Salami et al., 2018). The authors reported that that the addition of souring fruit extracts to germinated cereal grains significantly improved nutritional, and decreased the anti-nutritional properties of the samples. As previously stated, custard powder represent a suitable alternative to ogi for convenience. However, previous studies reported that the taste in terms of sourness of the custard paste needs to be improved (Salami et al., 2018). Therefore, in this study, the effect of souring agent on the functional, pasting and sensory properties of corn starch custard were investigated. Ogi prepared by fermentation was included as a reference sample.

\section{Materials and methods}

\section{Materials}

Yellow corn grains, corn starch (Aladdin Chemistry Company, Shanghai, China), flavour (vanilla), colourant (tartazine yellow), lime, soursop and tamarind were purchased from a local market in Ilorin, Kwara State, Nigeria. 


\section{Extraction of souring agents}

Tamarind juice was extracted according to the method described by Lee et al. (2009), soursop juice by the method of Quek et al. (2013), except that there was no microwave treatment, while lime juice was extracted by carefully squeezing out the juice after peeling the lime and thereafter separating the seeds using $0.25 \mathrm{~mm}$ size sieve.

\section{Custard formulation and addition of souring agents}

Custard was prepared using corn starch, vanilla flavor and tartrazine as previously reported (Akinwale et al., 2017). Souring agent (10\% w/w) was added to the custard powder after preliminary study. The preliminary study was done to establish the quantity of fruit extract required to give a comparable level of sourness to that of the corn gruel sample that was fermented. After several trials of varying concentration of the fruit extract using regular consumers of ogi, custard soured with $10 \%$ had comparable sourness rating with the corn gruel sample.

\section{Production of ogi}

Ogi was produced using the method reported by Laduni et al. (2015). Briefly, corn grains were sorted and soaked in distilled water for 72 hr. After decanting the steep water, the grains were milled and sieved through muslin cloth. The slurry was left to settle for another $12 \mathrm{hr}$ and then decanted again prior to drying. The slurry was dried at $60^{\circ} \mathrm{C}$ for $24 \mathrm{hr}$, milled, packaged in Ziploc bags and stored at $40^{\circ} \mathrm{C}$ prior to use.

\section{Functional properties of custard powder}

Swelling power of the samples was determined at a temperature range of 50 to $90^{\circ} \mathrm{C}$ as described by Madruga et al. (2014), while dispersibility was determined by the method of Kulkarni et al. (1991).

\section{Colour of powder and gruel}

Tristimulus $\mathrm{L}^{*} \mathrm{a}^{*} \mathrm{~b}^{*}$ parameters of the samples were determined after standardization using a colorFlex (A60-1014-593, USA). Snap shots in triplicates were taken and values were read directly from a digital print. Total colour difference $(\Delta \mathrm{E})$ was calculated according to equation 1 given below (Falade and Oyeyinka, 2015).

$$
\Delta E=\sqrt{(\Delta L)^{2}+(\Delta a)^{2}+(\Delta b)^{2}}
$$

\section{Pasting properties}

Pasting properties of the custard and gruel powder were measured using a Rapid Visco Analyser (RVA) (Newport Scientific Instruments, Warriewood, Australia), following the standard method described by the manufacturer. Briefly, sample ( $3 \mathrm{~g})$ was weighed into the test canister containing calculated amount of distilled water as specified by the instrument software. The sample was heated at $50{ }^{\circ} \mathrm{C}$ for $1 \mathrm{~min}$ for equilibration and then raised to $95{ }^{\circ} \mathrm{C}$ at $12^{\circ} \mathrm{C} / \mathrm{min}$. The sample was kept at $95{ }^{\circ} \mathrm{C}$ for $2.4 \mathrm{~min}$, cooled to $50{ }^{\circ} \mathrm{C}$ at $12^{\circ} \mathrm{C} / \mathrm{min}$ and finally main- tained at $50{ }^{\circ} \mathrm{C}$ for $2 \mathrm{~min}$. The peak time, pasting temperature, peak, trough, setback, breakdown and final viscosities of the samples were obtained from the instrument.

\section{Proximate composition}

Moisture, fat and ash contents were determined using AOAC (2000) methods. Protein content was determined by the Kjeldahl method $(6.25 \times N)$ and total carbohydrate was calculated by difference. Fibre contents were determined by digestion in sulfuric acid and sodium hydroxide (Kirk and Sawyer, 1991).

\section{Preparation of custard or corn gruel}

Custard or corn gruel was prepared as previously described (Akinwale et al., 2017). Briefly, the sample was poured into an appropriate sized bowl containing $60 \mathrm{ml}$ of water. The mixture was stirred continuously to a smooth mix with no lumps after which $240 \mathrm{ml}$ of hot water was added slowly for $10 \mathrm{~min}$ until the gruel was formed. The gruel was immediately dispensed into plates for sensory evaluation.

\section{Sensory analysis}

Sensory properties of corn and custard starch gruel was carried out by a fifty panel member comprising of students who are regular consumers of these products. The parameters evaluated were appearance, aroma, sourness, consistency and overall acceptability using a 9-point hedonic scale. The rating of samples ranged from 9 (like extremely), 8 (like very much), 7 (like moderately), 6 (like slightly), 5 (neither like nor dislike), 4 (dislike slightly), 3 (dislike moderately), 2 (dislike very much), 1 (dislike extremely).

\section{Statistical analysis}

Duplicate samples were prepared and analyses performed in triplicate. Data was analysed using one way analysis of variance (ANOVA) and means were compared using the Fisher Least Significant Difference (LSD) test $(\mathrm{p}<0.05)$.

\section{Results and discussion}

\section{Proximate composition}

Carbohydrate was the major component of the corn gruel $(61.72 \%)$ and the custard (66.27-74.42\%) samples (Table 1). The protein content of the corn gruel was substantially higher ( 3 times) than those of the custard samples (Table 1). This is expected since the custard samples were prepared from starch isolates and other ingredients, while the corn gruel is made from whole corn grain. The fermentation process may also have enhanced the protein content of the corn gruel. Previous research indicated that microorganisms utilise carbohydrates as an energy source resulting in a decrease of carbohydrate ratio in the total mass and subsequent redistribution of nutrient percentages (Onyango et al., 2004). This may explain the higher protein content of the corn gruel compared with the custard samples. Other components such as fibre (1.82-5.67\%), ash (4.63-4.82\%) and fat (0.08-4.29\%) contents of the samples were generally low (Table 1). 
Table 1. Proximate composition of corn gruel and soured corn starch custard (\%)

\begin{tabular}{cccccc}
\hline Parameters & Corn gruel & Custard & $\begin{array}{c}\text { Custard } \\
+ \text { tamarind }\end{array}$ & $\begin{array}{c}\text { Custard } \\
+ \text { soursop }\end{array}$ & $\begin{array}{c}\text { Custard } \\
+ \text { lime }\end{array}$ \\
\hline Moisture & $8.13^{\mathrm{c}} \pm 0.06$ & $9.42^{\mathrm{b}} \pm 0.03$ & $10.76^{\mathrm{a}} \pm 0.13$ & $7.28^{\mathrm{d}} \pm 0.03$ & $9.45^{\mathrm{b}} \pm 0.004$ \\
Protein & $18.03^{\mathrm{a}} \pm 0.40$ & $8.62^{\mathrm{b}} \pm 0.06$ & $8.41^{\mathrm{bc}} \pm 0.06$ & $8.03^{\mathrm{c}} \pm 0.008$ & $8.29^{\mathrm{b}} \pm 0.04$ \\
Ash & $4.82^{\mathrm{a}} \pm 0.05$ & $4.81^{\mathrm{a}} \pm 0.03$ & $4.63^{\mathrm{a}} \pm 0.12$ & $4.64^{\mathrm{a}} \pm 0.07$ & $4.79^{\mathrm{a}} \pm 0.06$ \\
Fibre & $3.01^{\mathrm{d}} \pm 0.01$ & $5.46^{\mathrm{b}} \pm 0.07$ & $1.82^{\mathrm{e}} \pm 0.03$ & $5.67^{\mathrm{a}} \pm 0.13$ & $4.30^{\mathrm{c}} \pm 0.01$ \\
Fat & $4.29^{\mathrm{a}} \pm 0.02$ & $0.08^{\mathrm{d}} \pm 0.04$ & $0.14^{\mathrm{c}} \pm 0.05$ & $0.24^{\mathrm{b}} \pm 0.06$ & $0.15^{\mathrm{c}} \pm 0.02$ \\
$*^{\text {CHO }}$ & $61.72^{\mathrm{e}} \pm 0.70$ & $71.60^{\mathrm{c}} \pm 0.07$ & $74.42^{\mathrm{a}} \pm 0.07$ & $66.27^{\mathrm{d}} \pm 0.04$ & $73.04^{\mathrm{b}} \pm 0.03$ \\
\hline
\end{tabular}

Values are Mean \pm S.D. Means with the same superscript within arow are not significantly $(p<0.05)$ different *CHO: Total carbohydrate

\section{Functional properties}

Custard powders were more dispersible in water than the corn gruel control sample (Figure 1), suggesting that the custard samples will have better reconstitution in water during cooking. Earlier researchers reported that the higher the dispersibility the better the reconstitution in water to give a fine and consistent paste (Eke-Ejiofor and Kiin-Kabari, 2010; Kulkarni et al., 1991). However, soured custard samples had reduced dispersibility compared with the custard powder without souring extract. This could be due to the presence of souring extracts from tamarind, soursop and lime which presumably caused clumping of the starch samples resulting in lower dispersibility.

Corn gruel and the custard samples showed similar swelling pattern, as swelling power of the samples progressively increased with increasing temperature from 50 to $60^{\circ} \mathrm{C}$ (Figure 2). All the samples displayed a rapid increase in swelling above heating temperature of $60^{\circ} \mathrm{C}$. The rapid increase in swelling power at temperatures above $70^{\circ} \mathrm{C}$ suggest the melting of starch crystallites, which confirms gelatinisation (Hoover and Sosulski, 1985). In general, all the custard samples displayed higher swelling power than the corn gruel at higher temperature range of 80 and $90^{\circ} \mathrm{C}$. This could be due to the presence of non-starch components such as lipids. Lipids can form helical inclusion complex with amylose in starch restricting starch granule hydration and swelling (Oyeyinka et al., 2016). The addition of souring fruit extract did not significantly affect the swelling power of the custard samples.

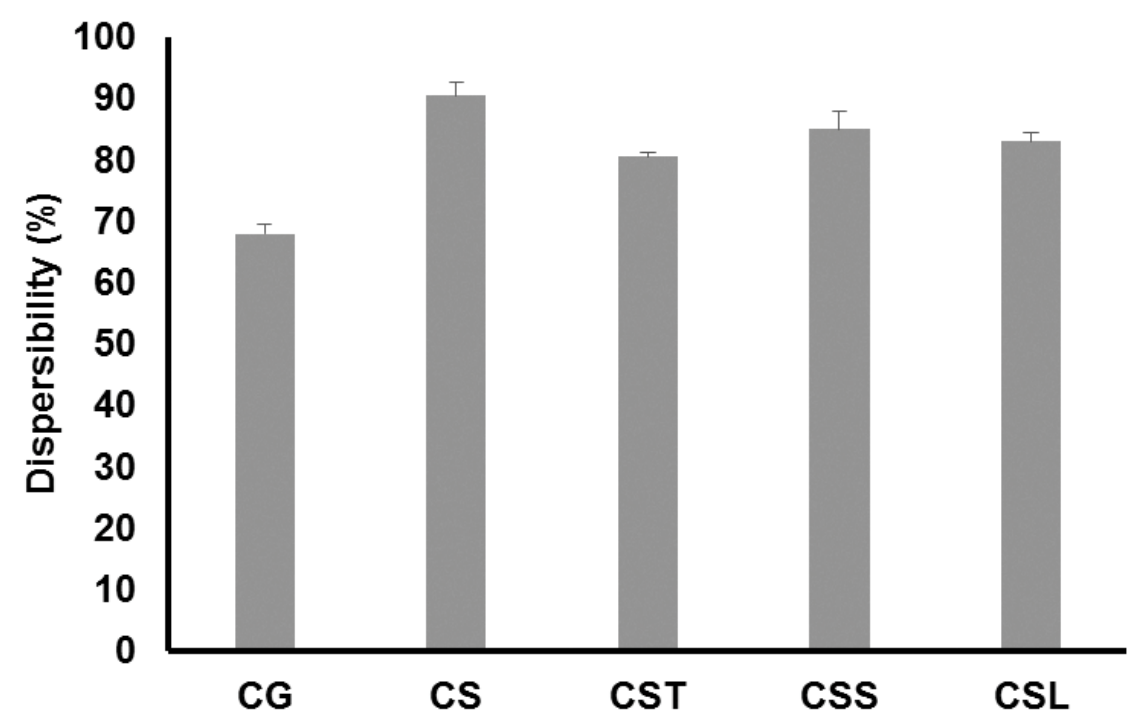

CG: Corn gruel

CS: Corn starch

CST: Corn starch + tamarind

CSS: Corn starch+ soursop

CSL: Corn starch+ lime

Figure 1: Dispersibility of soured custard samples 


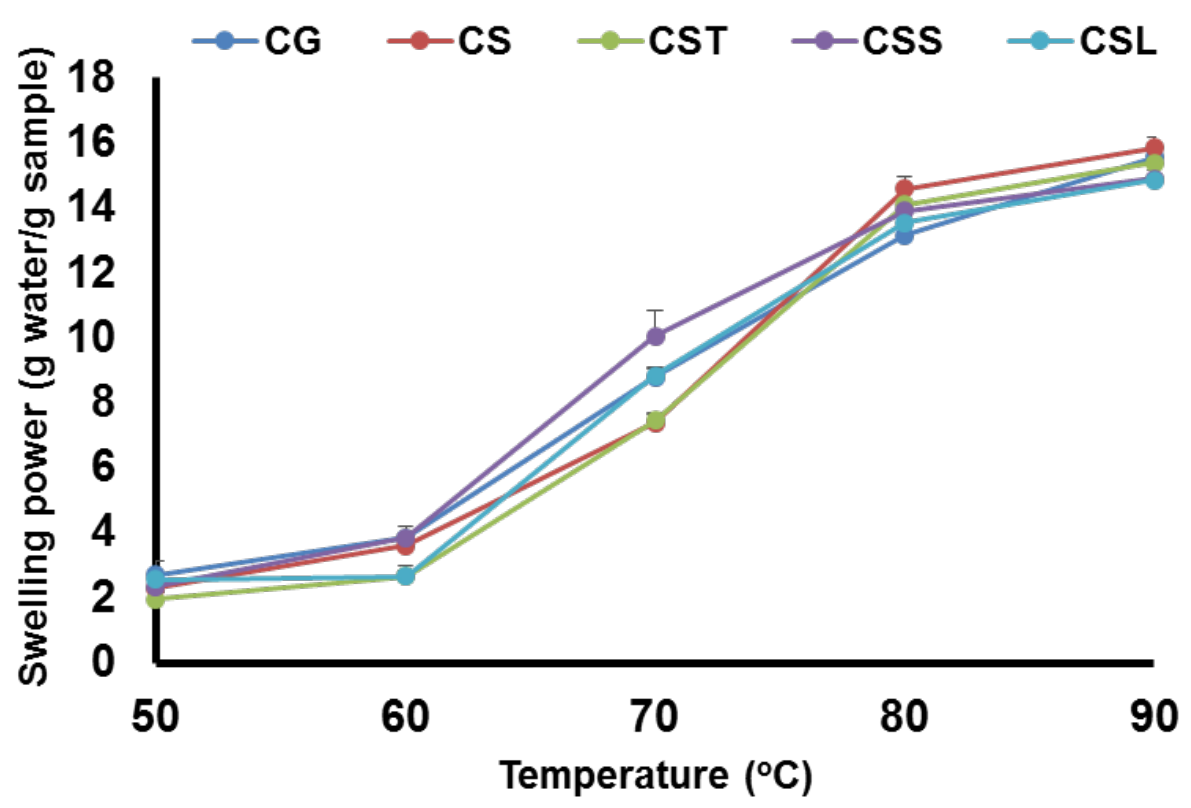

CG: Corn gruel

CS: Corn starch

CST: Corn starch + tamarind

CSS: Corn starch+ soursop

CSL: Corn starch+ lime

Figure 2: Swelling power of soured custard samples

\section{Pasting properties}

Custard samples and corn gruel had similar pasting curves (Figure 3), but showed significant differences in their pasting properties (Table 2). Soured custard samples generally showed significantly higher peak viscosities than the un-soured custard and corn gruel sample. Among the soured custard samples, custard soured with tamarind had lower peak viscosity (2506 cP) compared with custard soured with lime (2919 $\mathrm{cP})$ and custard soured with soursop $(3039 \mathrm{cP})$. Peak viscosity of starch is affected by several factors including the starch granule size, amylose content as well as the presence of non-starch components such as lipids that can form inclusion complexes with amylose (Tester and Morrison, 1990). The same starch was used in the current study, therefore, the apparent variation in the peak viscosities of the samples may be attributed to the respective viscosity of the souring extracts. For instance, previous studies reported the non-Newtonian behaviour $(\mathrm{n}<1)$ of soursop juice concentrates (Quek et al., 2013) and shear thinning behaviour of tamarind juice concentrates (Ahmed et al., 2007).

With or without the addition of souring agent, the final viscosities of the custard samples were higher than the corn gruel (Table 2). The addition of souring fruit extract improved the final viscosities of the custard samples. Soursop addition increased the final viscosity of custard by approximately $61 \%$, tamarind increased the viscosity by approximately $10 \%$, while lime increased it only slightly (approx. 1\%). The final viscosity result suggest that soursop is more viscous than lime and tamarind and this may explain the higher peak viscosity value recorded for custard sample soured with soursop. This seems plausible since the same amount of souring fruit extract was used.

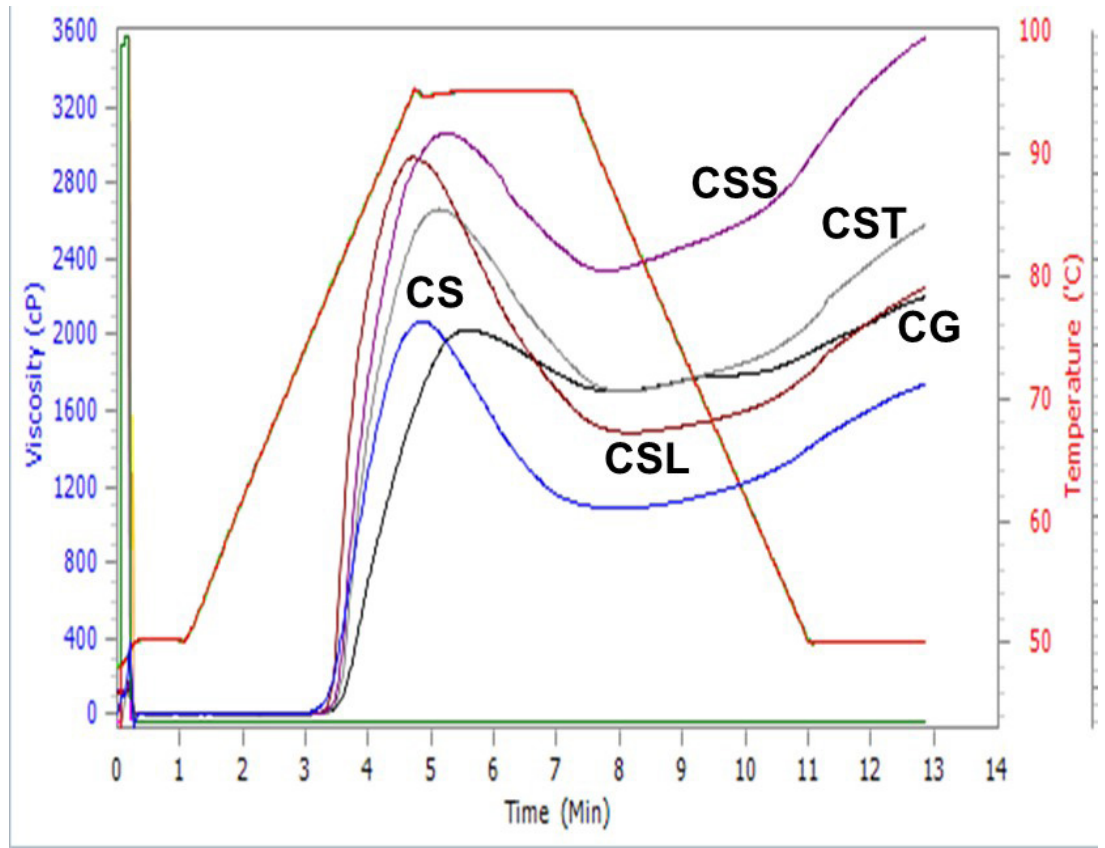

Figure 3: Typical pasting curve of soured custard samples

CG: Corn gruel

CS: Corn starch

CST: Corn starch + tamarind

CSS: Corn starch+ soursop

CSL: Corn starch+ lime 
Table 2. Pasting properties of soured custard

\begin{tabular}{cccccc}
\hline Sample & CG & CS & CST & CSS & CSL \\
\hline Peak viscosity (cP) & $2079.0^{\mathrm{c}} \pm 1.1$ & $2019.0^{\mathrm{c}} \pm 7.1$ & $2506.0^{\mathrm{b}} \pm 2.2$ & $3039.0^{\mathrm{a}} \pm 3.9$ & $2919.0^{\mathrm{a}} \pm 2.6$ \\
Trough viscosity (cP) & $1067.5^{\mathrm{d}} \pm 2.8$ & $1707.0^{\mathrm{b}} \pm 7.07$ & $1625.5^{\mathrm{b}} \pm 1.2$ & $2351.0^{\mathrm{a}} \pm 1.8$ & $1504.0^{\mathrm{c}} \pm 2.9$ \\
Breakdown viscosity (cP) & $1011.5^{\mathrm{b}} \pm 3.9$ & $362.0^{\mathrm{e}} \pm 5.6$ & $880.5^{\mathrm{c}} \pm 1.1$ & $714.5^{\mathrm{d}} \pm 1.3$ & $1437.5^{\mathrm{a}} \pm 1.7$ \\
Final viscosity (cP) & $1746.0^{\mathrm{c}} \pm 9.9$ & $2218.5^{\mathrm{b}} \pm 1.3$ & $2436.5^{\mathrm{b}} \pm 1.5$ & $3571.5^{\mathrm{a}} \pm 1.4$ & $2232.0^{\mathrm{b}} \pm 2.2^{\mathrm{a}}$ \\
Setback viscosity (cP) & $678.5^{\mathrm{d}} \pm 1.8$ & $535.0^{\mathrm{e}} \pm 2.4$ & $811.0^{\mathrm{b}} \pm 1.3$ & $1232.0^{\mathrm{a}} \pm 1.0$ & $790.0^{\mathrm{c}} \pm 1.4$ \\
Peak time (min) & $4.9^{\mathrm{d}} \pm 0.05$ & $5.6^{\mathrm{a}} \pm 0.02$ & $5.2^{\mathrm{c}} \pm 0.05$ & $5.3^{\mathrm{b}} \pm 0.02$ & $4.7^{\mathrm{e}} \pm 0.05$ \\
Pasting temperature $\left({ }^{\circ} \mathrm{C}\right)$ & $77.0^{\mathrm{b}} \pm 0.60$ & $79.4^{\mathrm{a}} \pm 0.71$ & $78.7^{\mathrm{a}} \pm 0.57$ & $78.7^{\mathrm{a}} \pm 0.46$ & $77.1^{\mathrm{b}} \pm 0.74$ \\
\hline
\end{tabular}

Values are mean \pm S.D. Mean with the same superscript along a row are not significantly $(p<0.05)$ different

CG: Corn gruel; CS: Corn starch; CST: Corn starch + tamarind; CSS: Corn starch + soursop; CSL: Corn starch + lime

Setback viscosities of the samples were significantly affected by the souring agents. Un-soured custard sample had the lowest setback value, while custard samples soured with soursop had the highest value. Setback ratio is a measure of the retrogradation tendencies of starch. Starches with low setback viscosities have low tendencies towards retrogradation (Qian and Kuhn, 1999). Thus, un-soured custard sample will have lower tendencies for retrogradation compared with the corn gruel and the custard samples. The time to peak which represent the time to cook the sample (4.7-5.6 $\mathrm{min}$ ) was slightly different among the samples, while the pasting temperatures were similar $\left(77.1-79.4^{\circ} \mathrm{C}\right)$. The pasting temperature of the samples are within the range reported for biofortified cassava starch-based custard $\left(75.18-76.68^{\circ} \mathrm{C}\right.$ ) (Awoyale et al., 2016) and for corn-banana custard flour $\left(75.05-82.45^{\circ} \mathrm{C}\right)$ (Alimi et al., 2017a).

\section{Colour of soured custard powder and paste}

The colour parameters of corn starch custard powder, the control fermented corn flour and their respective pastes are presented in Table 3. Lightness value $\left(\mathrm{L}^{*}\right)$, which indicates the degree of whiteness was very similar (87.37-90.33) across the samples (Table 3). The $L^{*}$ values of the custard starch samples (approx. 89) were slightly higher than the fermented corn flour (approx. 84). Previous studies reported L* value of approx. 86 for custard prepared from high quality cassava starch enriched with defatted soya bean (Alake et al., 2016).

The a values ranged between -5.44 and -3.91 for corn starch custard soured with tamarind and corn starch custard soured with lime respectively. In terms of the $b$ values which indicate degree of yellowness $\left(+b^{*}\right)$ and degree of greenness $\left(-b^{*}\right)$, the corn starch custard without any souring agent showed the lowest level (18.88) of yellowness compared to the corn gruel (27.24) and the soured corn starch custard (23.2927.79) (Table 3 ). Souring agents significantly increased the yellowness of the custard starch samples. Fermented corn flour and corn starch custard soured with lime showed the highest yellowness value which was very similar (approx. 27). The high yellowness value of the corn starch custard soured with lime may be due to the slightly yellow appearance of lime, while that of the corn gruel may be associated with the colour of the corn grain used for preparing the flour.

The appearance of corn gruel made from yellow maize was very different from the custard paste samples, but the custard paste showed similar appearance (Figure 4). Objective colour measurement of the custard paste showed that souring extracts increased the lightness values (Table 3 ). Souring extract had similar effect on the lightness of the custard samples. The yellowness (b) of the custard paste with (25.22-32.58) or without (29.86) souring extracts were generally higher than the corn gruel sample (21.22) (Table 2). This is expected since custard contains tartrazine, a food colourant used to confer the unique yellow colour of custard. The objective colour result is in agreement with the appearance of the sample (Figure 4). The total colour difference $(\Delta \mathrm{E})$ calculated from equation 1 revealed that the soured custard powder samples were closer in colour to the corn gruel than the un-soured custard sample since the latter showed greater $\Delta \mathrm{E}$ value (Table 2). The same trend was observed for their corresponding paste samples. Variation in $\Delta \mathrm{E}$ values among the samples obviously resulted from the souring agents, which presumably masked the colour of the tartrazine differently when compare with the un-soured custard sample.

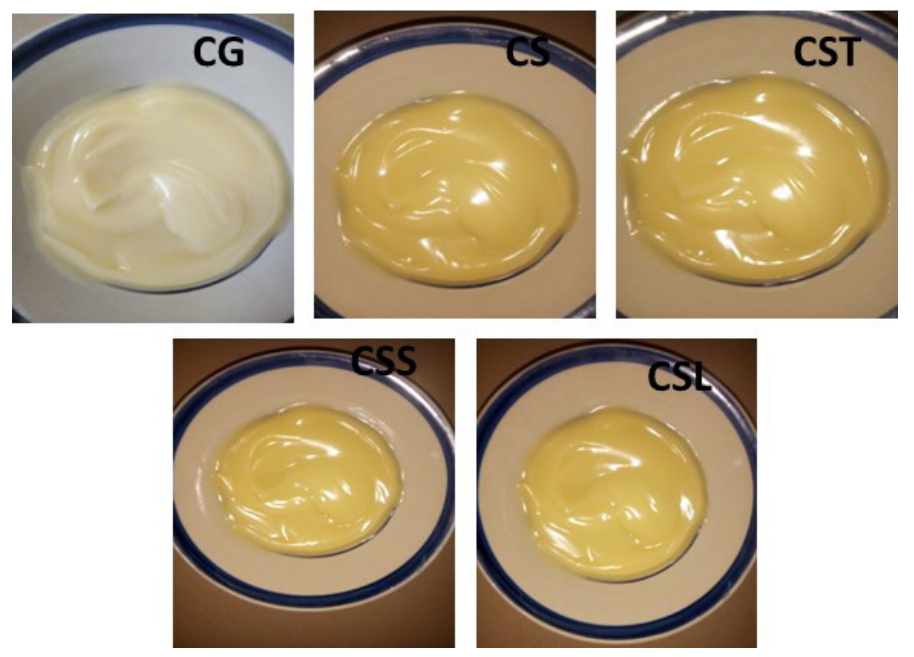

Figure 4: Appearance of corn gruel and custard paste samples

CG: Corn gruel

CS: Corn starch

CST: Corn starch + tamarind

CSS: Corn starch+ soursop

CSL: Corn starch+ lime 
Table 3: Colour parameters of soured custard powder and paste

\begin{tabular}{lcccccccc}
\hline \multicolumn{9}{c}{ Custard powder } \\
\hline Sample & $\mathrm{L}^{*}$ & $\mathrm{a}^{*}$ & $\mathrm{~b}^{*}$ & $\Delta \mathrm{E}$ & $\mathrm{L}^{*}$ & $\mathrm{a}^{*}$ & $\mathrm{~b}^{*}$ & $\Delta \mathrm{E}$ \\
\hline CG & $83.77^{\mathrm{b}} \pm 5.02$ & $-4.35^{\mathrm{a}^{\mathrm{b}} \pm 0.58}$ & $27.24^{\mathrm{a}} \pm 2.83$ & - & $62.08^{\mathrm{a}} \pm 4.52$ & $-7.39^{\mathrm{d}} \pm 0.09$ & $21.22^{\mathrm{d}} \pm 0.68$ & - \\
CS & $89.98^{\mathrm{a}} \pm 0.94$ & $-4.53^{\mathrm{b}} \pm 0.25$ & $18.88^{\mathrm{c}} \pm 0.34$ & $10.42^{\mathrm{a}} \pm 1.43$ & $45.03^{\mathrm{c}} \pm 1.18$ & $-5.48^{\mathrm{b}} \pm 0.16$ & $29.86^{\mathrm{b}} \pm 1.00$ & $19.21^{\mathrm{a}} \pm 0.21$ \\
CST & $90.33^{\mathrm{a}} \pm 2.99$ & $-5.44^{\mathrm{c}} \pm 0.19$ & $24.60^{\mathrm{b}} \pm 0.77$ & $7.16^{\mathrm{b}} \pm 0.83$ & $48.84^{\mathrm{b}} \pm 2.26$ & $-6.47^{\mathrm{c}} \pm 0.26$ & $29.27^{\mathrm{b}} \pm 1.99$ & $15.52^{\mathrm{b}} \pm 0.14$ \\
CSS & $87.37^{\mathrm{ab}} \pm 1.06$ & $-5.08^{\mathrm{c}} \pm 0.32$ & $23.29^{\mathrm{b}} \pm 0.61$ & $5.39^{\mathrm{c}} \pm 1.03$ & $48.26^{\mathrm{b}} \pm 0.24$ & $-4.76^{\mathrm{a}} \pm 0.10$ & $32.58^{\mathrm{a}} \pm 0.21$ & $18.08^{\mathrm{a}} \pm 1.12$ \\
CSL & $87.89^{\mathrm{ab}} \pm 1.31$ & $-3.91^{\mathrm{a}} \pm 0.16$ & $27.79^{\mathrm{a}} \pm 1.14$ & $4.18^{\mathrm{d}} \pm 0.24$ & $48.08^{\mathrm{b}} \pm 4.52$ & $-7.39^{\mathrm{d}} \pm 0.09$ & $25.22^{\mathrm{c}} \pm 0.68$ & $14.56^{\mathrm{b}} \pm 0.90$ \\
\hline
\end{tabular}

Values are mean \pm S.D. Means with same superscript within same column are not significantly $(p<0.05)$ different

CG: Corn gruel; CS: Corn starch; CST: Corn starch + tamarind; CSS: Corn starch + soursop; CSL: Corn starch + lime

\section{Sensory properties of soured custard samples}

Mean sensory scores of corn gruel and custard samples are presented in Table 4. In general, corn gruel samples had different ratings for appearance, aroma, sourness, consistency and overall acceptability compared with the custard samples. Custard samples had very similar ratings in all the sensory properties. Among the soured samples, custard soured with lime had the highest rating for sourness, while un-soured custard sample had the lowest. The high sourness rating for custard soured with lime could be due to the juicy white, stringy and sour taste of the lime fruit (Akubor and Egbekun, 2007).

Table 4: Sensory properties of soured custard samples

\begin{tabular}{lccccc}
\hline Sample & Appearance & Aroma & Sourness & Consistency & $\begin{array}{c}\text { Overall } \\
\text { acceptability }\end{array}$ \\
\hline Corn gruel & $6.36^{\mathrm{b}} \pm 1.63$ & $5.20^{\mathrm{b}} \pm 1.91$ & $6.08^{\mathrm{b}} \pm 1.93$ & $6.64^{\mathrm{c}} \pm 1.32$ & $5.98^{\mathrm{c}} \pm 1.85$ \\
Corn starch & $7.80^{\mathrm{a}} \pm 0.88$ & $7.52^{\mathrm{a}} \pm 1.02$ & $6.02^{\mathrm{b}} \pm 1.80$ & $7.80^{\mathrm{a}} \pm 0.95$ & $7.80^{\mathrm{a}} \pm 0.95$ \\
Corn starch + tamarind & $7.62^{\mathrm{a}} \pm 0.90$ & $7.42^{\mathrm{a}} \pm 0.94$ & $6.10^{\mathrm{b}} \pm 2.00$ & $7.02^{\mathrm{b}^{\mathrm{c}} \pm 0.93}$ & $7.38^{\mathrm{ab}^{\mathrm{b}} \pm 1.28}$ \\
Cornstarch + soursop & $7.55^{\mathrm{a}} \pm 0.73$ & $7.06^{\mathrm{a}} \pm 1.29$ & $6.06^{\mathrm{b}} \pm 1.77$ & $6.82^{\mathrm{c}} \pm 1.14$ & $7.25^{\mathrm{b}} \pm 1.21$ \\
Cornstarch + lime & $7.68^{\mathrm{a}} \pm 1.13$ & $7.26^{\mathrm{a}} \pm 1.16$ & $6.94^{\mathrm{a}} \pm 1.88$ & $7.44^{\mathrm{b}} \pm 1.56$ & $7.20^{\mathrm{b}} \pm 1.28$ \\
\hline
\end{tabular}

Values are mean \pm S.D. Means with same superscript within same column are not significantly $(P<0.05)$ different

In comparison with corn gruel, the custard sample had slightly higher sourness value than the corn gruel sample. The sourness of corn gruel is highly dependent on the length of fermentation, with longer fermentation period enhancing greater level of sourness. The low sourness value recorded for corn gruel may be due to the effect of drying on the lactic acid which is responsible for the sourness of corn gruel. The ratings for consistency was higher for custard samples than for corn gruel, which agree with the dispersibility result (Figure 1). On the whole, the overall acceptability of the un-soured custard sample was similar to custard sample soured with tamarind but significantly $(\mathrm{p}<0.05)$ higher than custard soured with soursop and lime.

\section{Conclusions}

Soured custard samples showed better functionality compared with the un-soured sample and corn gruel. Addition of souring agent did not significantly alter the cooking time and pasting temperature of the custard samples. Custard may be soured with lime, tamarind and soursop to improve dispersibility, consistency, viscosity and sourness. Custard sample soured with tamarind show comparable acceptability with the un-soured sample. Souring agents seem to mask the colour of tartrazine reducing the colour difference when compared with the un-soured custard sample, indicating soured samples were closer to the corn gruel control.

Authors declare no conflict of interest. The research was self-funded.

\section{References}

Ahmed J., Ramaswamy H., Sashidhar K. (2007) Rheological characteristics of tamarind (Tamarindus indica L.) juice concentrates. LWT-Food Science and Technology, 40 225-231.

Akinwale T., Niniola D., Abass A., Shittu T., Adebowale A., Awoyale W., Awonorin S., Adewuyi S., Eromosele, C. (2017) Screening of some cassava starches for their potential applications in custard and salad cream productions. Journal of Food Measurement and Characterization, 11 299-309.

Akubor P., Egbekun, M. (2007) Chemical Composition, Physical and Sensory Characteristics of Echekala (Spondias mombin) Fruit Juice. 
Nigerian Journal of Nutrition Science, 28 1-8.

Alake O., Babajide J., Adebowale A., Adebisi, M. (2016) Evaluation of physico-chemical properties and sensory attributes of cassava enriched custard powder. Cogent Food \& Agriculture, 21246116.

Alimi B., Sibomana M., Workneh T., Oke, M. (2017a) Some Engineering Properties of Composite Corn-Banana Custard Flour. Journal of Food Process Engineering, 40 e12444.

Alimi B. A., Workneh,T. S., Oyeyinka, S. A. (2017b) Structural, rheological and in-vitro digestibility properties of composite corn-banana starch custard paste. LWT-Food Science and Technology, 79 84-91.

AOAC (2000) Offcial Methods of Analysis. 17th edition. In: Asscoaition of official Analytical Chemists, Rockville.

Awoyale W., Sanni L., Shittu T., Adegunwa, M. (2016) The pasting, chemical and sensory properties of biofortified cassava root starch-based custard powder. Journal of Food Measurement and Characterization, 10 292-301.

Eke-Ejiofor J., Kiin-Kabari, D. (2010) Chemical, pasting, functional and sensory properties of sweet and Irish potato chips. Nigeria Food Journal, 28 47-48.

Falade K.O., Oyeyinka, S.A. (2015) Color, Chemical and Functional Properties of Plantain Cultivars and Cooking Banana Flour as Affected by Drying Method and Maturity. Journal of Food Processing and Preservation, 39 816-828.

Hoover R., Sosulski F. (1985) Studies on the functional characteristics and digestibility of starches from Phaseolus vulgaris biotypes. StarchStärke, 37 181-191.

Kirk S., Sawyer R. (1991) Pearson's composition and analysis of foods, England Longman scientific and technical: Longman Group Ltd.

Kulkarni K. D., Kulkarni D., Ingle U. (1991) Sorghum malt-based weaning food formulations: Preparation, functional properties and nutritive value. Food and Nutrition Bulletin, 13 322-327.

Laduni E., Oyeyinka A. T., Oyeyinka S. A., Aworh C. O. (2015). Effect of drying method and cereal type on functional and pasting properties of ogi powder. Ukrainian Food Journal, 4 587-595.

Lee J. W., Kim J. K., Srinivasan P., Choi J.-i., Kim J. H., Han S. B., Kim D.-J., Byun M. W. (2009) Effect of gamma irradiation on microbial analysis, antioxidant activity, sugar content and color of ready-to-use tamarind juice during storage. LWT-Food Science and Technology, 42 101-105.

Madruga M. S., de Albuquerque F. S. M., Silva I. R. A., do Amaral D. S., Magnani M., Queiroga Neto, V. (2014) Chemical, morphological and functional properties of Brazilian jackfruit (Artocarpus heterophyllus L.) seeds starch. Food Chemistry, 143 440-445.

Obulesu M., Bhattacharya S. (2011) Color changes of tamarind (Tamarindus indica L.) pulp during fruit development, ripening, and storage. International Journal of Food Properties, 14 538-549.

Okoye J., Nkwocha A., Agbo, A. (2008) Nutrient composition and acceptability of soy-fortified custard. Continental Journal of Food Science and Technology, 2 37-44.

Onyango C., Noetzold H., Bley T., Henle T. (2004) Proximate composition and digestibility of fermented and extruded uji from maize-finger millet blend. LWT-Food Science and Technology, 37 827-832.

Oyeyinka S. A., Singh S., Ma, Y., Amonsou E. O. (2016) Influence of high-pressure homogenization on the physicochemical properties of bambara starch complexed with lysophosphatidylcholine. LWT-Food Science and Technology, 74 120-127.

Qian J., Kuhn, M. (1999) Characterization of Amaranthus cruentus and Chenopodium quinoa starch. Starch-Stärke, 51 116-120.

Que M. C., Chin N. L., Yusof Y. A. (2013) Modelling of rheological behaviour of soursop juice concentrates using shear rate-temperature-concentration superposition. Journal of Food Engineering, 118 380-386.

Salami K. O., Akinoso R., Oyeyinka S. A., Kayode, R.-M.-O. (2018) Proximate, anti-nutrient composition and sensory properties of germinated cereal grain with added souring fruit extracts Annals. Food Science and Technology 19 275-282.

Shankaracharya N. (1998). Tamarind-chemistry, technology and uses-a critical appraisal. Journal of Food Science and Technology, 35 193-208.

Tárrega A., Costell E. (2006). Effect of inulin addition on rheological and sensory properties of fat-free starch-based dairy desserts. International Dairy Journal, 16 1104-1112.

Tester R. F., Morrison W. R., (1990) Swelling and gelatinization of cereal starches. I. Effects of amylopectin, amylose and lipids. Cereal Chemistry, 67 551-557. 